\title{
PERAN SEL STELATA HEPATIK PADA SIROSIS HEPATIS
}

\author{
Iola Pattabang \\ Sunny Wangko \\ Bagian Anatomi Histologi Fakultas Kedokteran Universitas Sam Ratulangi Manado \\ e-mail: sunnywangko@yahoo.com
}

\begin{abstract}
Hepatic stellate cells was first described by Carl von Kupffer in 1876 by using gold chloride staining. Stellate cells are located in space of Disse, a space between hepatocytes and sinusoidal endothelial cells. The main function of stellate cells is vitamin A storage. In hepatic cirrhosis, these stellate cells diffeerentiate to become myofibroblast and produce extracellular matrix.
\end{abstract}

Keywords: stellate cells, function

\begin{abstract}
Abstrak: Sel stelata hepatik pertama kali dideskripsikan oleh Carl Von Kupffer tahun 1876 dengan menggunakan metode pewarnaan gold chloride. Sel stelata terletak dalam celah Disse, yaitu celah antara hepatosit dan sel endotel sinusoid. Fungsi utama dari sel stelata adalah menyimpan vitamin A. Pada sirosis hepatis sel stelata akan berubah menjadi miofibroblas dan memproduksi matriks ekstrasel.
\end{abstract}

Kata kunci: sel stelata, fungsi

Penelusuran pertama pengenalan sel ini dimulai dari surat Carl Von Kupffer yang menulis untuk seorang ahli anatomi Waldeyer pada tahun 1876. Von Kupffer mempelajari sistem saraf hepatik. Ia mewarnai saraf hepatik dengan menggunakan metode pewarnaan gold chloride dan mendapatkan gambaran sel berbentuk bintang (sternzellen). Pengaturan teknik pewarnaan sesudah itu yang digunakan untuk mengidentifikasi sel stelata, mencakup metode perak golgi digunakan oleh Zimmerman untuk mengidentifikasi hepatic pericytes, metode pewarnaan lemak digunakan oleh Ito untuk mendefenisikan fat storing cell, dan teknik impregnasi perak digunakan oleh Suzuki untuk menggambarkan interstitial cell. Penelitian selanjutnya, Bronfenmajer, Schaffner, dan Popper mengusulkan nama lipocyte un-tuk menggambarkan peran sel stelata dalam mengambil lemak (vitamin A) dan menekankan kesamaan sel ini dengan fibroblast. ${ }^{1-3}$

Akhirnya, pada awal 1970, Kenjiro Wake dan Nakane tiba pada kesimpulan bahwa star-shaped phagocyte yang dideskripsikan oleh Kupffer, identik dengan fat-storing cell yang dideskripsikan oleh Ito. Wake dan Nakane menetapkan sel stelata sebagai sel khusus yang mempunyai kemampuan menyimpan vitamin A. Wake menggunakan metode gold chloride yang dulu pernah digunakan oleh Kuppfer untuk memberikan gambaran pasti dari sel stelata in situ, dengan demikian menetapkannya sebagai perisinusoidal cell..$^{2,3}$

Dengan berkembangnya penelitian 
dari sel stelata, timbul kebingungan karena memiliki banyak nama yang berbeda. Pada tahun 1996 kelompok peneliti internasional yang bekerja aktif pada topik ini merekomendasikan untuk mengarahkan tipe sel ini sebagai hepatic stellate cell. ${ }^{3}$ Nama lain dari sel ini adalah perisinusoidal cell, Ito cell, lipocyte, parasinusoidal cell, dan fatstoring cell. ${ }^{1-4}$ Asal embrionik sel stelata sulit untuk dipahami. Sekarang ini buktibukti mendukung asal dari sel ini adalah endoderm atau septum transversum mesenkim. Sel stelata muncul pada pertengahan bulan ketiga dalam masa kehamilan. Akan tetapi ketika sel stelata ditemukan terdapat pada host penanda protein neural, diduga bahwa sel stelata bisa juga berasal dari neuroektodermal. Akhirnya penelitian terbaru pada manusia menduga bahwa sel stelata dapat juga berasal dari prekursor sum-sum tulang.,

\section{Morfologi}

Sel stelata hepatik terletak dalam celah Disse, yaitu celah antara hepatosit dan sel endotel sinusoid. Jumlah sel ini kira-kira 1-3 sel nonparenkim dan 15\% dari jumlah total sel residen dalam hati normal 1,2,4,6,7 Sel stelata dalam hati normal mempunyai badan sel berbentuk kumparan-kerucut dengan inti oval atau memanjang. Perikarionnya berdekatan dengan sel parenkim. Gambaran ultrastuktur terdiri dari retikulum endoplasma kasar, kompleks jukstanuklear golgi dan tonjolan sitoplasma bercabang. Tonjolan subendotel membungkus mengelilingi sinusoid antara sel sinusoid dan hepatosit. Pada setiap tonjolan ini banyak terdapat tonjolan-tonjolan kecil. Sel stelata tunggal pada umumnya mengelilingi lebih dari dua sinusoid yang berdekatan. Pada sisi lain dari sel (permukaan anti-luminal), penonjolan melewati sampai celah Disse untuk membuat kontak dengan hepatosit. Hubungan yang baik antara sel stelata dan sel yang berdekatan dengan mereka mungkin memudahkan transpor interseluler dari mediator dan sitokin 2,3 Fungsi dari sel stelata dalam hati normal adalah menyimpan vitamin A (retinoid) dalam sitoplasma. Secara fluoresens vitamin A lebih banyak terkonsentrasi dalam daerah periportal daripada daerah pericentral. Dua jenis vitamin A yg telah diuraikan: jenis I adalah membrane bound dengan ukuran yang tidak tetap tapi pada umumnya lebih kecil dari 2 $\mu \mathrm{m}$. Jenis ini mungkin berasal dari badan yang mana dipertimbangkan sebagai jenis dari lisosom. ${ }^{3,9}$

Jenis II bukan membrane bound dan ukurannya lebih besar (sampai 8 $\mu \mathrm{m})$. Hubungan antara jenis I dan II dan perbedaan fungsinya adalah belum jelas. Menurut Wake, jenis II adalah penyatuan dari beberapa jenis I. Akan tetapi Yamamoto dan Ogawa percaya jenis II untuk prekursor jenis I. Selama kerusakan hati, struktur sel stelata mengalami perubahan seperti pembesaran retikulum endoplasma dan pengerutan membran inti. Sel stelata kehilangan vitamin A dan akan teraktivasi. Sel stelata yang telah diaktivasi kemudian berubah menjadi miofibroblas . 2,3,8,9

\section{Fungsi sel stelata hepatik pada hati normal}

- Berperan dalam perkembangan dan regenerasi hati. Fungsi penting sel ini didukung oleh fakta bahwa pada hati fetus tikus diperoleh sel-sel Thy $1^{+}$, yang mengekspresikan gambaran klasik sel stelata hepatik ( $\alpha$-SMA, desmin, dan vimentin), meningkatkan maturasi progenitor hepatik melalui kontak sel-sel dalam kultur. Sel stelata juga mengekspresikan epimorphin, suatu pro- 
tein morphogen mesenkimal yang dapat mengalami peningkatan sesudah hepatektomi parsial. Selain itu sel stelata juga menyekresikan derived-morphogen, pleitropin, dan dapat memberi kontribusi terhadap regenerasi hepatosit. $^{2}$

- Metabolisme retinoid. Pada hati normal sel stelata memainkan peranan kunci dalam penyimpanan dan transpor retinoid (senyawa vitamin A). Dibawah kondisi fisiologik ini, $50-80 \%$ dari total retinoid tubuh disimpan dalam hati, dimana $80-90 \%$ tersimpan dalam sel stelata. Kebanyakan vitamin A tersimpan dalam droplet cytoplasmic dalam bentuk retinil ester. Droplet tidak hanya mengandung retinoid, tapi juga sejumlah trigliserida, fosfolipid, kolesterol, dan asam lemak bebas. $^{2,9}$

- Imunoregulator. Munculnya sel stelata sebagai mediator signifikan dari imunoregulasi hepatik merupakan salah satu penemuan-penemu- an yang mengejutkan mengenai tipe sel ini. Sel-sel stelata dapat memperkuat respon-respon inflamasi melalui induksi infiltrasi leukosit mononuklear dan polimorfonuklear. $^{2}$

- Sekresi Lipoprotein, growth factor, dan sitokin. Sel stelata adalah sumber penting sitokin dalam hati. Pada hakekatnya sel stelata tidak hanya menyekresi sitokin tapi juga berespon terhadap sitokin-sitokin ini. Beberapa contoh sitokin yang disekresi oleh sel stelata adalah tumor growth factor- $\alpha$ (TGF- $\alpha$ ), epidermal growth factor (EGF), Platelet-derived growth factor (PDGF), IL-6, LPS, IL-1 $\beta$, macrophage colony-stimulating factor (M-CSF), MCP-1, ICAM-1, VCAM-1, neural cell adhesion molecule (NCAM), Endothelin-1 (ET-1), HGF, insulin-like growth factor (IGF) I dan II, connective tissue growth factor (CTGF).,

Tabel 1. Faktor parakrin yang terlibat dalam pengaktifan sel stelata hepatik ${ }^{11}$

\begin{tabular}{ll}
\hline \multicolumn{1}{c}{ Sumber } & \multicolumn{1}{c}{ Faktor parakrin } \\
\hline Hepatosit & Lipid peroksida, TGF $\square$ 1, TGF $\square$, IL-6, IGF-1, IGFBP, M-CSF, \\
& GM-CSF \\
Sel Kupffer & Lipid peroksida, TGFb1, TGFa, IL-6, TNFa, PDGF, \\
Sel endotel & TGFb1, ET-1, PDGF, aktivasi TGFb1 \\
Platelet & PDGF, TGFb1, EGF \\
Limfosit & TGFa, Interleukin \\
Monosit & TNFa,TGFb1, PDGF \\
\hline
\end{tabular}

\section{Respon-respon sel stelata hepatik pada kerusakan dan perbaikan hati}

1. Aktivasi sel stelata hepatik

"Aktivasi" sel stelata merujuk pada konversi sel yang kaya vitamin A menjadi sel yang berproliferasi, fibrogenik dan kontraktil. Aktivasi terdiri dari dua fase utama yaitu inisiasi dan perpetuasi, diikuti oleh resolusi fibrosis jika kerusakan mereda. Inisiasi (juga disebut stadium preinflamasi) merujuk pada perubahan awal dalam ekspresi dan fenotip gen yang menyebabkan sel-sel responsif terhadap sitokin dan stimuli lain. Inisiasi 
kebanyakan terjadi dari stimulasi parakrin (tabel 1), terutama menyebabkan perubahan sekeliling matriks ekstra-sel, demikian juga paparan terhadap lipid peroksida dan produk-produk kerusakan hepatosit. ${ }^{8,10,11}$

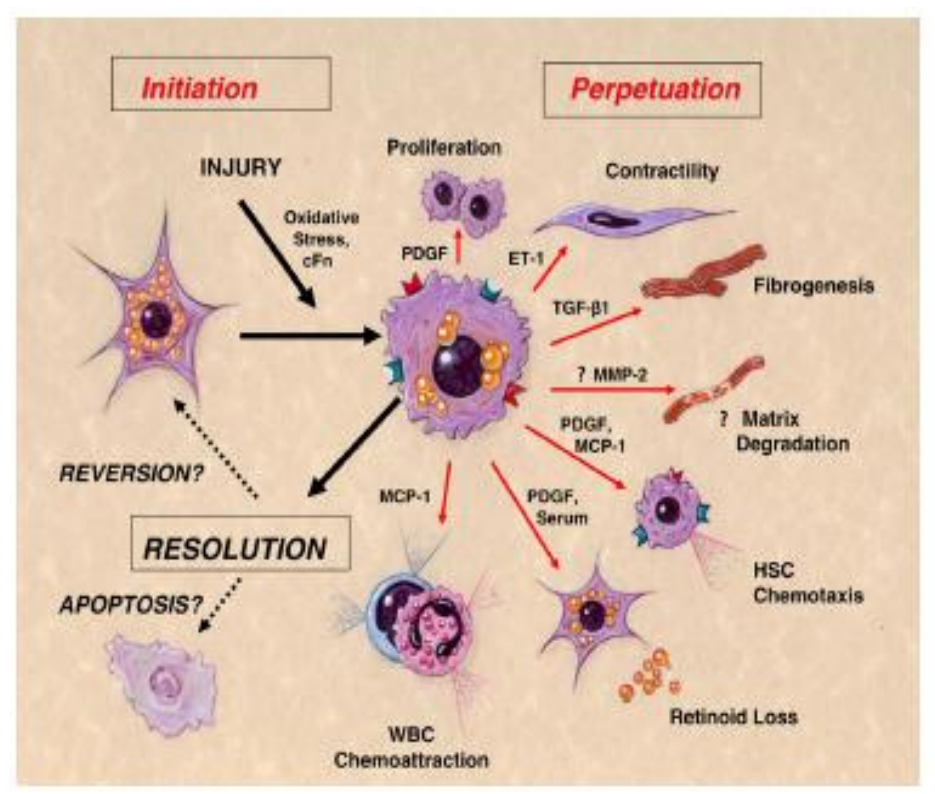

Gambar 4. Aktivasi sel stelata hepatik Sumber: Friedman $(2004)^{2}$

Tabel 2. Faktor autokrin dan parakrin yang terlibat dalam pengaktifan sel stelata hepatik ${ }^{11}$

\begin{tabular}{cc}
\hline Perubahan & Faktor \\
\hline Proliferasi & PDGF, EGF, TGF $\alpha$, bFGF, IGF-1, CTGF \\
Kemotaksis sel stelata & PDGF, bFGF, IGF-1, M-CSF, MCP-1 \\
Kemotaksis leukosit & M-CSF,MCP-1 \\
Fibrogenesis & TGF $\beta 1$, asetaldehid, retinoid, IL1- $\beta$, IL-6 TNF $\alpha$ \\
Kontraktilitas & ET-1, PAF, Nitrit Oksida, trombin \\
Degradasi matriks & MMP- $2+$ MMP-9 $\downarrow$ ECM normal, $\downarrow$ MMP-1 $(\downarrow$ skar ECM), \\
Kehilangan retinoid & $\uparrow$ TIMP1 \\
& $\downarrow$ ligand untuk RAR + RXR \\
\hline
\end{tabular}

Perpetuasi terjadi dari efek-efek stimuli ini untuk mempertahankan fenotip yang teraktivasi dan membangkitkan fibrosis. Perpetuasi melibatkan autokrin demikian juga parakrin (tabel 2). Prosesproses ini terdiri dari berbagai responrespon khas termasuk proliferasi, kontraktilitas, fibrogenesis, degradasi matriks, kehilangan retinoid, dan infiltrasi sel inflamasi. ${ }^{3,8,11,12}$

\section{Interaksi sel stelata hepatik dengan sel-sel hati lainnya}

Sel-sel stelata ada dalam lingkungan multiselular dimana terjadi interaksi sel ke sel yang mendasari regulasi ketat kontrol homeostatik bagi fungsi hati 
normal dan respon-respon terhadap penyakit.

- Hepatosit dan sel-sel stelata bekerja sama dalam metabolisme retinoid dimana senyawa yang pertama diambil oleh hepatosit, kemudian ditransfer ke penyimpanan sel stelata. Pada hati yang mengalami kerusakan, hepatosit adalah sumber poten lipid peroksidase fibrogenik dan fragmen-fragmen Fas-mediated apoptotic, demikian juga reaktan fase akut dan aktivator plasminogen. $\alpha 2$ Macroglobulin diperkuat oleh hepatosit dapat menurunkan fibrogenesis melalui pengambilan TGF- $\beta$. Komunikasi silang sitokin sama penting dan termasuk TGF- $\beta$, TGF- $\alpha$, insulin-like growth factor dan binding protein, $\mathrm{HGF}$, VEGF, NGF, CTGF, IL-6, thrombospondin, demikian juga faktor-faktor parakrin lain yang berasal dari sel tumor hepatik. Sel-sel stelata juga mendukung fungsi hepatosit ex vivo, dimana akan berlanjut ke arah perkembangan perlengkapan pendukung hati. Terdapat fakta lain bahwa hepatosit yang terinfeksi HCV dapat melepaskan faktor-faktor fibrogenik ke arah sel-sel stelata dimana dapat menjelaskan mengapa pasien dengan transaminase serum normal terinfeksi dengan HCV tetap mengalami perkembangan fibrosis hepatik. $^{2}$

- Interaksi-interaksi sel stelata dengan sel Kupffer terjadi diantara interaksi parakrin pertama yang diuraikan diantara sel-sel nonparenkimal dalam hati dan dapat berperan menjadi profibrotik atau antifibrotik. Infiltrasi sel Kupffer secara khas mendahului aktivasi sel stelata pada hewan percobaaan dengan kerusakan hati. Pelepasan mediator kemotaktik, mi- salnya MCP-1 atau osteopontin, memberi kontribusi infiltrasinya. Mediator fibrogenik asal sel Kupffer termasuk TGF- $\beta$ dan lipid peroxida. Dalam menyokong peranannya dalam aktivasi sel stelata, inaktivasi sel Kupffer melalui gadolinium chloride yang menurunkan aktivasi sel stelata dan fibrosis pada hewan coba. Pada hemakromatosis, akumulasi besi dalam sel Kupffer dan makrofag dipikirkan menginduksi aktivasi sel stelata. Sel Kupffer juga dapat distimulasi melalui fragmenfragmen apoptotik untuk melepaskan mediator-mediator fibrogenik. Dilain pihak, sel Kupffer dapat menstimulasi apoptosis sel stelata. Komunikasi silang antara sel stelata dan sel Kupffer terjadi setelah paparan terhadap LPS yang juga mengganggu regenerasi hati. ${ }^{2}$

- Sel-sel stelata dan sel endotel sinusoid memiliki prekursor embriogenik yang sama. Fakta ini, dikombinasikan dengan kedekatan fisiknya yang erat, membuat interaksi parakrin sangat mungkin dan secara potensial penting. Pelepasan protease yang terkontrol dan terkoordinasi merupakan kejadian awal yang kritis pada regenerasi hati, mungkin untuk aktivasi mitogen laten termasuk HGF. Kedua tipe sel menunjukkan induksi terkoordinasi reseptor VEGF selama kerusakan hati. Sebagai tambahan, perubahan awal bentuk fibronektin seluler dipicu oleh aktivasi endotel sinusoid yang digerakkan oleh sel-sel stelata hepatik. Jalur lain gabungan antara dua tipe sel ini, termasuk TGF- $\beta$, IGF-I, leptin, plasminogen, endothelin, dan nitric oxide. ${ }^{2}$ 


\section{KESIMPULAN}

- Sel stelata hepatik adalah sel nonparenkimal yang terletak dalam celah Disse, di mana fungsi utamanya adalah menyimpan vitamin A. Sel stelata mempunyai ukuran yang kecil, berbentuk kumparan atau bintang dengan beberapa penjuluran dan mempunyai inti yang berbentuk oval atau vesikuler.

- Sel stelata berperan dalam terjadinya sirosis hepatis. Pada sirosis hepatis sel ini akan teraktivasi dan, melepaskan cadangan retinil ester, dan berubah menjadi sel mirip fibroblas yang sangat berperan dalam pembentukan matriks ekstra-sel yang mengandung kolagen, proteoglikan, dan glikoprotein.

\section{DAFTAR PUSTAKA}

1. Grets A, Grunsven L, et al. Biology of hepatic stellate cells and liver progenitor cells [online]. 2004 [Cited 2009 April 16 ]. Available from: URL: http://cyto.vub.ac.be/

2. Friedman S. Hepatic stellate cells: Protean, Multifunctional, and Enigmatic Cells of the Liver.US patent 125-172, 2008. Available from: URL:http//physrev.physiology.org/c gi/ content /full//88/1/125\#BIBL

3. Pinzani M. The hepatic stellate cell. In J Rodes, Benhamou J, Blei A, Reichen J, Rizzetto M. Hepatology, architecture of the liver. $3^{\text {nd }}$ ed. Oxford University Press, 2007: 43-50

4. Wikipedia. Ito cell [online]. June 2009 [Cited 2009 July 12] Available from: URL: http://wapedia.mobi/en/ Ito_cell

5. Miyata E, Masuya M, Yoshida S. Hematopoietic origin of hepatic stellate cells in the adult liver. US patent 2427-2435, 2007 November 27. Available from: URL: http:// bloodjournal.hematologylibrary.org/ cgi/reprint/111/4/2427

6. Junqueira C, Carniero J. Histologi Dasar, edisi 10. Alih bahasa Jan Tambayong . Jakarta: EGC, 2007: 320-321

7. Lelosutan SA. Peranan hepatopro-tektor pada penyakit hati kronik [online]. 10 April 2008 [cited 1 Juli 2009]. Available from: URL: http://forahmi. org/index.php? option=com_content\& task=view\&id=30\&Itemid=31

8. Handaryani E, Ochiai K, Winarto A. Extrahepatic bile duct ligation in broiler chickens: ultrastructural study of Ito cell. US patent JITV 9(4): 252-257, 2004.

9. Blaner WS, O'Byrne SM, et al. Hepatic stellate cell lipid droplet: A specialized lipid for retinoid storage [online]. 2008 November 24 [cited 2009 July 2]. Available from: URL:http:// www.ncbi.nlm.nih.gov/ pubmed/19071229

10. Brando d, Ramalho $L$, et al. Liver cirrhosis and hepatic stellate cells [online]. Acta Cir. Bras. vol. 21 suppl.1 São Paulo 2006 [cited 2009 April 17]. Available from: URL: http//www.scielo.br/scielo.php?scrip $\mathrm{t}=$ sciscielo.php?script=S010286502006000700013

11. Reeves H, Friedman S. Activation of hepatic cells-a key issue in liver fibrosis. Frontiers in Bioscince 7, d808-826 [paten online]. 2002 [cited 2009 April 2].

12. Moreira RK. Hepatic stellate cell and fibrosis liver [online]. 2007 April 24 [cited 2009 July 1]. Available from: URL: http:// findarticles.com/p/ articles/mi_qa3725//is_200711/ai_n2 1137391. 